\title{
The Australian INDIgenous Business EXEMPTION AS A 'SPECIAL MEASURE': QUESTIONS OF EFFECTIVENESS
}

\section{MATTHEW STOREY*}

This article considers the issue of the requirements of establishing the Australian Commonwealth government's Indigenous preferential procurement program, the 'indigenous business exemption' as a special measure under Article 1.4 of the International Convention on the Elimination of All Forms of Racial Discrimination. It does this by, considering jurisprudence regarding special measures and other affirmative action programs from Australia and other jurisdictions, concluding that it is necessary to establish some evidential base to justify the establishment (in Australian law) and ongoing operation of such measures (in international law). The article then examines the effectiveness of procurement policies aimed at achieving secondary social objectives in addition to the primary procurement of government goods and services.

\section{INTRODUCTION}

This discussion examines the issue of the extent to which it is necessary to be able to demonstrate a factual basis in order to legitimise the establishment and maintenance of a program as a special measure under both the Racial Discrimination Act 1975 (Cth) ('RDA') and the International Convention for the Elimination of All Forms of Racial Discrimination 1 ('the Convention'). The context of this examination is a program under which enterprises owned by Indigenous Australians receive preferential consideration in the award of Australian Commonwealth Government procurement contracts.

\footnotetext{
${ }^{*}$ Chief Executive Officer, Native Title Services Victoria; University Fellow, Charles Darwin University School of Law; DBA Candidate, Deakin University Faculty of Law and Business. The author thanks Professor Stuart Orr and the anonymous referee for their useful comments on earlier drafts of this article.

${ }^{1}$ International Convention on the Elimination of All Forms of Racial Discrimination, opened for signature 21 December 1965, 660 UNTS 195 (entered into force 4 January 1969).
} 
The Commonwealth Procurement Rules 2014 ('CPR')2 issued by the Minister for Finance under section $105 \mathrm{~B}(1)$ of the Public Governance, Performance and Accountability Act 2013 (Cth) at Division 1 demand that all procurements by a Commonwealth department or agency demonstrate value for money and adhere to the key principles of public procurement such as non-discrimination, the encouragement of competition, and ethicality. Division 2 of the $C P R$ also insists that the procurement of goods and services of a value of greater than $\$ 80,000$ or the commissioning of construction projects of a value greater than $\$ 7.5$ million be by way of public tender. However, the $C P R$ also contains provisions that exempt an agency from the Division 2 requirement for public tender if the contract is awarded to a firm with greater than 50 per cent Indigenous ownership that employs fewer than 200 employees and where 'value for money' can be demonstrated. ${ }^{3}$ This exemption from the usual Commonwealth procurement tender requirements, which was included in the CPR from 2011, is known as the 'Indigenous business exemption' ('IBE').

In July 2015 the Commonwealth government expanded upon the IBE when it announced its 'Indigenous Procurement Policy' ('IPP'). The IPP builds upon the IBE by requiring that a percentage of all Commonwealth procurement contracts $(0.5$ per cent in 2015-16 increasing to 2.5 per cent by 2018-19) are awarded to Indigenousowned firms, and by introducing a mandatory requirement that procurement contracts of a value between $\$ 80,000$ and $\$ 200,000$ for provision of goods and services in remote areas must be awarded to Indigenous-owned firms. In essence the IPP adds a policy overlay onto the IBE but leaves the original IBE in place.

Quite clearly the original IBE and the new IPP facilitates, and in some circumstances demands, discrimination on the basis of race. On its face then, the IBE would appear to offend section $9(1)$ of the $R D A$ which contains the fundamental prohibition against doing an act involving a 'distinction, exclusion, restriction or preference based on race'. The $R D A$ gives domestic effect in Australia to the Convention.

The risk of unlawfulness under section 9(1) of the $R D A$ can only be met with a response that the IBE is exempt from the application of section $9(1)$ on the basis that (pursuant to section $8(1)$ of the $R D A$ ) the IBE constitutes a 'special measure' for the purposes of Article 1.4 of the Convention, which provides (emphasis added):

Special measures taken for the sole purpose of securing adequate advancement of certain racial or ethnic groups or individuals requiring such protection as may be necessary in order to ensure such groups or individuals equal enjoyment or exercise

\footnotetext{
${ }^{2}$ Department of Finance, Commonwealth Procurement Rules 2014, Statutory Instrument $(2014)<\mathrm{http}: / /$ www.

finance.gov.au/sites/default/files/2014\%20Commonwealth\%20Procurement\%20Rules.pdf $>$. ${ }^{3}$ Department of the Prime Minister and Cabinet, Commonwealth Indigenous Procurement Policy (2015) <http://www.dpmc.gov.au/indigenous-affairs/publication/factsheet-usingcommonwealth-procurement-rules-indigenous-exemption-no17-meet-indigenousprocurement-policy>.
} 
of human rights and fundamental freedoms shall not be deemed racial discrimination, provided, however, that such measures do not, as a consequence, lead to the maintenance of separate rights for different racial groups and that they shall not be continued after the objectives for which they were taken have been achieved.

The main goal of this current discussion is to investigate the extent to which it is necessary for the Commonwealth government to be able to demonstrate that the IBE is a legitimate response 'necessary in order to ensure [Indigenous Australians'] equal enjoyment or exercise of human rights and fundamental freedoms' and to be able to demonstrate that the IBE is effective in this goal.

To achieve this goal, the discussion will proceed in three parts. The first part considers Australian and international jurisprudence surrounding the concept of 'special measures' within the Convention. This examination will involve consideration of not only Article 1.4 but also Article 2.2. Some regard to the jurisprudence from the United States ('US') with regard to 'minority' procurement set asides as considered in Adarand Constructors Inc $v$ Pena $^{4}$ is included in this consideration, as is very briefly some jurisprudence from the European Court of Justice ('ECJ'). The purpose of this comparative analysis is to highlight the different approaches taken to the factual basis considered necessary to support characterisation of an apparently racially discriminatory policy as a special measure.

This examination will suggest that it is necessary for the Commonwealth to be able to identify that Indigenous Australians do not currently have equal enjoyment or exercise of human rights and freedoms in order to characterise a program as a special measure. Further, that under domestic law it is also necessary to show that the IBE is 'appropriate and adapted' 5 to redressing this situation. The discussion continues on to suggest that at international law it is also necessary to demonstrate that a program is effective in remedying the original unequal enjoyment or exercise of human rights and freedoms. This approach it is suggested is similar to the evidential approach required under US affirmative action jurisprudence. This part of the discussion concludes by noting that in order to be able to demonstrate the effectiveness of a program it is necessary to have in place mechanisms to undertake the monitoring and evaluation of the program.

The next two parts of the discussion focus upon some of the evidential issues identified as necessary above. Part two examines the position of Australia's Indigenous peoples with a view to first establish the need for implementation of a special measure; and, second, to review literature that considers whether the fostering of Indigenous enterprise as contemplated by the IBE can be expected to remedy the unequal enjoyment of 'human rights and fundamental freedoms'. This examination is aimed at exploring whether the IBE can be considered as 'appropriate and adapted'

\footnotetext{
${ }^{4} 115$ US 2097 (1995) ('Adarand').

${ }^{5}$ Gerhardy v Brown (1985) 159 CLR 70, 149 (Deane J) ('Gerhardy').
} 
as a special measure in accordance with domestic jurisprudence. The final part considers the issue of whether the IBE can be expected to be successful in fostering Indigenous enterprise. To this end, this part identifies the use made of the IBE to date and reviews existing literature regarding the effectiveness of procurement policies such as the IBE designed to achieve 'secondary objectives' in addition to the primary objective of obtaining goods and services on behalf of government more generally. The discussion then moves to consider the need for and approaches to the monitoring and evaluation of programs such as the IBE in light of the concluding discussion in part two that identified such mechanisms as an ongoing requirement of a special measure.

The article concludes by emphasising need for the ongoing effectiveness of the IBE to be monitored over time.

\section{Special Measures}

Within the Convention the concept of special measures is utilised on two occasions. The first is in Article 1.4 which has been reproduced above. The second is in Article 2.2 the terms of which are also worth noting:

States Parties shall, when the circumstances so warrant, take, in the social, economic, cultural and other fields, special and concrete measures to ensure the adequate development and protection of certain racial groups or individuals belonging to them, for the purpose of guaranteeing them the full and equal enjoyment of human rights and fundamental freedoms. These measures shall in no case entail as a consequence the maintenance of unequal or separate rights for different racial groups after the objectives for which they were taken have been achieved.

The Committee on the Elimination of Racial Discrimination ('CERD') established under the Convention in its General Recommendation $32^{6}$ notes that: '[Article 2.2] carries forward the special measures concept [contained in Article 1.4] into the realm of obligations of States parties' (emphasis added). ${ }^{7}$

While most Australian judicial consideration of special measures has been focused on the Convention, the special measures approach is found in other international instruments as well. Prominent amongst these are Articles 4.1 and 4.2 of the

\footnotetext{
${ }^{6} \mathrm{UN}$ Committee on the Elimination of Racial Discrimination, General Recommendation No 32: The Meaning and Scope of Special Measures in the International Convention on the Elimination of All Forms [of] Racial Discrimination, CERD/C/GC/32 (24 September 2009).

${ }^{7}$ The fact that art 2.2 creates an obligation on states to implement special measures where appropriate is also noted in Gerhardy (1985) 159 CLR 70, 96 (Mason J), 138 (Brennan J), although Brennan $\mathrm{J}$ also noted that this obligation is not enforceable in municipal court.
} 
Convention on the Elimination of All Forms of Discrimination against Women ('CEDAW'). ${ }^{8}$ Article 4.1 of CEDAW provides:

Adoption by States parties of temporary special measures aimed at accelerating de facto equality between men and women shall not be considered discrimination as defined in the present Convention, but shall in no way entail as a consequence the maintenance of unequal or separate standards; these measures shall be discontinued when the objectives of equality of opportunity and treatment have been achieved.

CEDAW Article 4.1 creates a regime permissive of special measures in the nature of the Convention Article 1.4, unlike the obligation created under the Convention Article 2.2. While these special measures provisions are quite well known, perhaps less obvious is the potential obligation for states to develop special measures that is contained in the 1948 Universal Declaration of Human Rights ('UDHR'). ${ }^{9}$ As Ginsburg and Merritt argue, while the UDHR may not contain an explicit special measures provision in the nature of the Convention Article 2.2, provisions such as Article 25 ('Everyone has the right to a standard of living adequate for the health and well-being of himself and of his family, including food, clothing, housing and medical care and necessary social services ...') imply that:

[i]f a nation finds that citizens of one race — or sex or religion — endure a markedly inadequate standard of living, then Article 25 suggests an obligation to uncover the cause of, and respond to, that endurance. ${ }^{10}$

The same authors suggest a similar obligation arises from a number of other UDHR provisions such as Articles 23, 26 and 29.

Despite a clearly respectable pedigree in international human rights law, as the cases considered below indicate, the appropriateness of special measures is often hotly contested. One clue as to the basis of this contest may be found in General Recommendation 32. ${ }^{11}$ The CERD notes that special measures under the Convention are also referred to as 'affirmative measures', 'affirmative action' or 'positive action'. ${ }^{12}$ The CERD goes on to note "[t]he term "positive discrimination" is, in the context of international human rights standards, a contradicto in terminis and should be avoided'. ${ }^{13}$

\footnotetext{
${ }^{8} \mathrm{UN}$ General Assembly, Convention on the Elimination of All Forms of Discrimination Against Women, opened for signature 18 December 1979, 1249 UNTS 13.

${ }^{9}$ UN General Assembly, Universal Declaration of Human Rights, opened for signature 10 December 1948, 217 A(III).

${ }^{10}$ R Ginsburg and D Merritt, 'Affirmative Action: A Human Rights Dialogue' (1999) 21

Cardozo Law Review 253, 257.

${ }^{11}$ CERD, above $\mathrm{n} 6$.

12 Ibid [12].

${ }^{13}$ Ibid.
} 
It is perhaps this apparent contradiction that has led to 'special measures' being such a contested method for achieving functional equality in a society. Whatever the basis there can be no doubt about the reality of the contest around the legitimacy of 'special measures'. To illustrate this point jurisprudence from both the US and Europe will be considered before returning to consider Australian cases.

\section{A United States}

The jurisprudence regarding special measures in the US arises in the context of cases that have considered the constitutionality of affirmative action programs that have been impugned as contravening the 'equal protection clause' of section 1 of the $14^{\text {th }}$ Amendment to the US Constitution. ${ }^{14}$ As can be imagined, the $14^{\text {th }}$ Amendment, in particular the equal protection clause, has been litigated in many significant cases starting with Strauder $v$ West Virginia ${ }^{15}$ (constitutionality of all white juries), and including Brown $v$ Board of Education of Topeka ${ }^{16}$ constitutionality of school segregation). In 1973 Roe $v$ Wade ${ }^{17}$ involved consideration of the $14^{\text {th }}$ Amendment's due process clause.

Thus an appreciation of the US Supreme Court's approach to affirmative action (special measures) programs involves some appreciation of the Court's approach to government legislation or programs that may, at first blush, appear to infringe constitutionally guaranteed rights including, but not limited to, equal protection (for example, free speech or privacy matters are also included in this discourse). This approach is often categorised as 'three tiered'. ${ }^{18}$ Under this approach programs based upon 'suspect' classifications, such as race, alienage and national origin or that involve restrictions of fundamental rights such as the right to speech or vote are subject to 'strict scrutiny'. ${ }^{19}$ Those based on semi-suspect classifications such as gender or illegitimacy will be subject to 'intermediate scrutiny'. Programs that do not burden rights or involve suspect classes are subject only to a 'rational basis' test. This last test requires the program 'be rationally related to a legitimate objective'. ${ }^{20}$

\footnotetext{
14 'All persons born or naturalised in the United States and subject to the jurisdiction thereof are citizens of the United States and of the State wherein they reside. No State shall make or enforce any law which shall abridge the privileges or immunities of citizens of the United States; nor shall any State deprive any person of life, liberty or property without due process of law; nor deny to any person within its jurisdiction the equal protection of the law' (emphasis added). In Bolling v Sharpe, 347 US 497 (1954), the US Supreme Court held that the provisions of the $14^{\text {th }}$ Amendment were applicable also to the federal government.

${ }^{15} 100$ US 303 (1880).

${ }^{16} 347$ US 483 (1954).

${ }^{17} 410$ US 113 (1973).

${ }^{18}$ A Bhagwat, 'Purpose Scrutiny in Constitutional Analysis' (1997) 85(2) California Law Review 297.

${ }^{19}$ Ibid 303. See also PJ Rubin, 'Reconnecting Doctrine and Purpose: A Comprehensive Approach to Strict Scrutiny after Adarand and Shaw' (2000) 149 University of Pennsylvania Law Review 1, 13.

${ }^{20}$ Bhagwat, above n 18, 303.
} 
Intermediate scrutiny requires that a program be 'substantially related to the achievement of an important government interest'. ${ }^{21}$

Strict scrutiny requires that the program be 'narrowly tailored to advance a compelling government interest'. ${ }^{22}$

The historical origins of the application of the strict scrutiny test to programs involving an aspect of racial classification apparently lie in the early $1960 \mathrm{~s} .{ }^{23}$ The application of strict scrutiny to affirmative action programs though was at first unclear. An early example of consideration of the issue was Defunis v Odegaard. ${ }^{24}$ This case involved affirmative action in university entry although that matter was left unresolved on technical grounds.

The suspicion with which affirmative action programs have been viewed in US jurisprudence is aptly summed up in University of California $v$ Bakke: 'Racial and ethnic distinctions of any sort are inherently suspect and thus call for the most exacting judicial examination. ${ }^{25}$

Despite this, in Steelworkers $v$ Weber, ${ }^{26}$ the lawfulness of a voluntary employment affirmative action program was upheld. However, in City of Richmond v JA Croson $\mathrm{Co}^{27}$ the strict scrutiny standard was applied to determine a 'set-aside' program of the City of Richmond as unlawful. The case was seen as applying to all state and local government programs. ${ }^{28}$ Shortly after Croson though, the intermediate scrutiny standard was applied to uphold the validity of a program requiring the set aside of particular broadcasting licences to ethnic minority groups in Metro Broadcasting $v$ Federal Communications Commission. ${ }^{29}$

In Adarand Constructors Inc $v$ Pena ${ }^{30}$ the Court was quite definitive in applying strict scrutiny to federal affirmative action programs. Specifically, the Supreme Court (by a 5:4 majority) found:

\footnotetext{
${ }^{21}$ Ibid.

${ }^{22}$ Ibid. See also RH Fallon, 'Strict Judicial Scrutiny' (2007) 54 UCLA Law Review 1267, 1273 citing Johnson v California 543 US 499, 505 (2005).

${ }^{23}$ Fallon, above n 22, 1277 suggests McLaughlin v Florida 379 US 184 (1964) but notes that Brown and Bolling should also be seen as part of the discourse.

${ }^{24} 416$ US 312 (1974).

${ }^{25}$ University of California v Bakke 438 US 265, 290-1 (1978).

${ }^{26} 443$ US 193 (1979).

${ }^{27} 480$ US 469 (1989).

${ }^{28}$ M Rice and M Mongkuo, 'Did Adarand Kill Minority Set-Asides?' (1998) 58(1) Public Administration Review 82, 84. See also US Commission on Civil Rights, Federal Procurement after Adarand Report (2005)

$<$ https://www.law.umaryland.edu/marshall/usccr/documents/fedprocafteradarand.pdf $>$.

${ }^{29} 497$ US 557 (1990).

${ }^{30} 115$ US 2097 (1995).
} 


\begin{abstract}
'Because racial characteristics so seldom provide a relevant basis for disparate treatment, and because classifications based on race are potentially so harmful to the entire body politic, it is especially important that the reasons for any such classification be clearly identified and unquestionably legitimate,' and that '[r]acial classifications are simply too pernicious to permit any but the most exact connection between justification and classification.' We think that requiring strict scrutiny is the best way to ensure that courts will consistently give racial classifications that kind of detailed examination, both as to ends and as to means. ${ }^{31}$
\end{abstract}

The practical result of Adarand is that affirmative action programs in government procurement must, or at least should, be based on a 'disparity analysis' of the disparity between the 'number of qualified minority contractors willing and able to perform the service and the number of such contractors engaged'. ${ }^{32}$ This requirement for disparity analysis appears to have been adopted as the evidential base required to satisfy 'strict scrutiny'. 33

It is worthwhile to note that the acceptance of an affirmative action program as plausibly valid, subject to application of the strict scrutiny analysis, involves acceptance of the notion that such a program is one that at least could be 'narrowly tailored to advance a compelling government interest'. This involves acceptance that eliminating systemic or indirect discrimination is a matter of compelling government interest. $^{34}$

The issue was identified by the Court in Adarand where their Honours were at pains to point out that the application of strict scrutiny did not mean that affirmative action programs were therefore prohibited absolutely:

Finally, we wish to dispel the notion that strict scrutiny is 'strict in theory, but fatal in fact.' Fullilove, supra, at 519 (Marshall, J, concurring in judgment). The unhappy persistence of both the practice and the lingering effects of racial discrimination against minority groups in this country is an unfortunate reality, and government is not disqualified from acting in response to it. ${ }^{35}$

In fact a study of state and local government measures undertaken seven years after the Croson decision imposed the strict scrutiny test found little impact on the prevalence of the special measures problems; in fact, in many states the disparity analysis had led to an increase in special measures programs. ${ }^{36}$ Similarly a number

\footnotetext{
${ }^{31}$ Adarand, 115 US 2097 [236] (1995) (O’Connor J) citing Fullilove v Klutznick, 448 US $448,553-5,555$ (1980).

${ }^{32}$ Rice and Mongkuo, above n 28; see also US Commission on Civil Rights, above n 28.

${ }^{33}$ US Commission on Civil Rights, above $\mathrm{n} 28,1$.

${ }^{34}$ See Fallon above $\mathrm{n} 22,1321$.

${ }^{35}$ Adarand, 115 US 2097 [237] (1995) (O’Connor J) citing Fullilove v Klutznick, 448 US 448, 519 (1980).

${ }^{36}$ M Enchautegui, M Fix, P Loprest, S von der Lippe, and D Wissoker Do Minority Owned Businesses Get a Fair Share of Government Contracts? Report (Urban Institute, 1997) 49
} 
of federal programs (especially those under section 8(a) of the Small Business Act) ${ }^{37}$ have continued despite post Adarand challenges. ${ }^{38}$ This includes the setting of government wide goals ( 5 per cent) for procurement from socially disadvantaged businesses. Implementation of these goals is variable across agencies with the overall program managed by the Small Business Administration established under the Small Business Act. ${ }^{39}$

In summary, US constitutional law allows for the operation of affirmative action (special measures) programs but through the application of strict scrutiny requires an identifiable evidential foundation (in the form of disparity analysis) to justify their establishment. Notably, however, while US case law suggests the need for actual evidence to support the establishment of a special measures program there is no explicit requirement for ongoing monitoring as to whether the program achieves its goals and should be discontinued. This noted it would presumably be open to a plaintiff to challenge the ongoing operation of an affirmative action program if they believed a change of circumstances warranted it.

\section{B Europe}

The European Union ('EU') also has struggled with the legitimacy of the inclusion of criteria designed to enhance social equality in public procurement. The basic principle is contained in Article 2 of Directive 2004/18/EC ('the Procurement Directive' $)^{40}$ which provides:

Contracting authorities shall treat economic operators equally and nondiscriminatorily and shall act in a transparent way.

This prohibition of discrimination in the award of contracts sits uncomfortably with special measures. ${ }^{41}$ Attempts to specify social (or environmental) requirements in a tender specification are specifically addressed in Article 23 of the Procurement Directive:

\footnotetext{
$<$ http://www.urban.org/research /publication/do-minority-owned-businesses-get-fair-sharegovernment-contracts $>$.

${ }^{37} 15$ USC Ch 14A (Minority Small Business and Capital Ownership program). Under this program the Small Business Administration department assumes the role of head contractor and allocates subcontracts to minority businesses.

${ }^{38}$ US Commission on Civil Rights, above n 28, 130.

${ }^{39}$ Ibid 143.

${ }^{40}$ Directive 2004/18/EC of the European Parliament and of the Council of 31 March 2004 on the co-ordination of procedures for the award of public works contracts, public supply contracts and public service contracts $<$ http://eur-lex.europa.eu/legalcontent/EN/TXT/PDF/?uri=CELEX:32004L0018\&from=EN>. See also Directive 2004/17/EC regarding Construction Services.

${ }^{41}$ A specific exception is made with regard to 'sheltered workshops' in art 19 of the Procurement Directive.
} 
Which stipulate that technical specifications must not reduce competition, must be transparent and must not discriminate against possible contractors from outside the Member State of the contracting authority. ${ }^{42}$

The tension created from the prohibition on discrimination and the desire to use procurement to further social objectives has led to a number of cases before the ECJ. Cases from Beentjes ${ }^{43}$ in 1988 to Max Havelaar ${ }^{44}$ in 2012 have, however, suggested an uncomfortable and limited acceptance of such policies. ${ }^{45}$ As Muller-Wrede notes, in the Max Havelaar case, the ECJ found:

compliance with the [tender] 'criteria of sustainability of purchases and socially responsible business' and the obligation to 'contribute to improving the sustainability of the coffee market and to environmentally, socially and economically responsible coffee production' are not sufficiently clear, precise and unequivocal and therefore infringe the transparency obligation stipulated in Article 2 of the Directive. ${ }^{46}$

The result is that the ECJ has imposed strict controls around the use of such policies - demanding a strict 'subject matter of the contract nexus' with the social policy in question $^{47}$ in a manner not dissimilar to the US 'strict scrutiny' jurisprudence.

\section{Australia}

In Australia the caution with which special measures are viewed is similarly apparent in judicial opinion. In Gerhardy, the Australian High Court was prepared to accept legislation that limited access to a large tract of land on the basis of membership of a racial group, but only after intense scrutiny and subject to an express requirement that the policy encapsulated in the discriminatory legislation was 'appropriate and adapted' to ending the systemic original unequal enjoyment or exercise of human rights. In reaching this conclusion Justice Brennan identified four indicia of a legitimate special measure in the following passage:

A special measure (1) confers a benefit on some or all members of a class, (2) the membership of which is based on race, colour, descent, or national or ethnic origin, (3) for the sole purpose of securing adequate advancement of the beneficiaries in order that they may enjoy and exercise equally with others human rights and fundamental freedoms, (4) in circumstances where the protection given to the

\footnotetext{
${ }^{42}$ European Commission, Buying Social: A Guide to Taking into Account Social Considerations in Public Procurement (2010)

$<\mathrm{http} / /$ ec.europa.eu/social/main.jsp?langId=en\&catId=89\&newsId=978>.

${ }^{43}$ Beentjes (C-31/87) [1988] ECR 04635.

${ }^{44}$ European Commission v Kingdom of Netherlands (C-368) [2012] ECR.

${ }^{45}$ Procurement Directive art 26 allowing for 'special conditions relating to the performance of a contract' provides some limited scope for this.

${ }^{46}$ M Muller-Wrede, 'Sustainable Purchasing in the Aftermath of the ECJ's "Max Havelaar" Judgment' (2012 7(2) European Procurement \& Public Private Partnership Law Review 110,115 .

${ }^{47}$ Ibid 117.
} 
beneficiaries by the special measure is necessary in order that they may enjoy and exercise equally with others human rights and fundamental freedoms. ${ }^{48}$

In a lengthy analysis of these indicia, his Honour made a number of points relevant to the current discussion, the first being 'the beneficiaries of the special measure are natural persons not corporations'. ${ }^{49}$ His Honour noted in this context that a benefit conferred on an (Aboriginal) corporation may lead to benefits to natural persons, and that the purpose of a special measure may be gleaned from the terms of the legislation (if relevant) and other circumstances, and that the question of whether a measure leads to 'advancement' of a group can only be made by reference to the wishes of that group. ${ }^{50}$ Further, he noted that:

To determine whether the measure in question is intended to remove and is necessary to remove inequality in fact (as distinct from formal inequality) the circumstances affecting the political, economic, social, cultural and other aspects of the lives of the disadvantaged group must be known and an opinion formed as to whether the measure is necessary and likely to be effective to improve those circumstances. ${ }^{51}$

His Honour uncovered a certain tension here as the process outlined may involve questions that are essentially political and a 'court is ill-equipped to answer a political question'. ${ }^{52}$ This noted, it is still incumbent on a court to consider whether 'the political assessment inherent in the measure [could] reasonably be made?'. ${ }^{53}$ To do this it is 'also necessary to find, as matters of fact, the circumstances affecting the racial group and the effect which the special measure is likely to have on those circumstances'. 54

Justice Deane echoed these sentiments, noting that the Court did not have before it sufficient evidence to form a view on the factual circumstances leading to the implementation of the measure ${ }^{55}$ but that 'a finding that a provision was "taken" for a "sole purpose" ... will not be precluded unless it appears that the provision is not capable of being reasonably considered appropriate and adapted to achieving that purpose'. ${ }^{56}$ His Honour noted a certain limitation though in commenting: 'the Court

\footnotetext{
${ }^{48}$ Gerhardy (1985) 159 CLR 70, 133 (Brennan J).

${ }^{49}$ Ibid.

${ }^{50}$ Ibid 135.

${ }^{51}$ Ibid 137.

${ }^{52}$ Ibid 138.

${ }^{53}$ Ibid 139.

${ }^{54}$ Ibid. To similar effect see also 88 (Gibbs CJ); 104-5 (Mason J); 108 (Murphy J). His

Honour suggested that evidence to displace a presumption that the necessary factual circumstance to support the legislation would be necessary to impugn its validity.

${ }^{55}$ Ibid 152 (Deane J).

${ }^{56}$ Ibid 153 . His Honour made a similar point at 149 . The 'appropriate and adapted' construction is also used by Mason J at 105.
} 
is not concerned to determine whether the provisions are the appropriate ones to achieve, or whether they will in fact achieve, the particular purpose'. ${ }^{7}$

More recently in Maloney $v$ The Queen ${ }^{58}$ the High Court affirmed Gerhardy including the requirement that there needed to be a factual basis to support the legitimacy of a special measure and a requirement that the special measure be 'reasonably necessary' in order to redress discrimination. ${ }^{59}$ In reaching this view most of the various judgments expressly endorse the approach of Brennan and Deane JJ in Gerhardy as outlined above. ${ }^{60}$ The concept of reasonable necessity developed in the context of the Australian Constitution's prohibition against discrimination against interstate trade. ${ }^{61}$

While generally following the analytic structure posited by Brennan J in Gerhardy, Hayne $\mathbf{J}$ concluded that in determining whether a special measure is 'adequate' it is appropriate for a court to consider whether the same 'advancement' of a group denied full enjoyment of human rights could be achieved by a method less intrusive on the rights of other members of the community. ${ }^{62}$

Crennan J referred to the US jurisprudence discussed above, ${ }^{63}$ but in the context of suggesting that Australian courts would not subject a special measure to strict scrutiny. Her Honour opined that there was no material before the Court to suggest that alternative measures were more appropriate. ${ }^{64}$

Similarly (in obiter) Kiefel $\mathbf{J}$ opined that while the Court would consider whether there are reasonably practical alternative measures to the impugned measure:

[t]he existence of any possible alternative is not sufficient to show that the measure chosen was not reasonably necessary according to the test. An alternative measure needs to be equally effective, before a Court can conclude that the measure is a disproportionate response. ${ }^{65}$

Somewhat by contrast, Bell J while adopting the application of 'reasonable necessity' considered that to be so classified a law must be 'proportionate to the legitimate end it seeks to serve' but that this does not require a court to consider 'whether there are reasonably available alternatives to the problem which are less restrictive of the

\footnotetext{
${ }^{57}$ Ibid 149.

${ }^{58}$ (2013) 252 CLR 168 ('Maloney').

${ }^{59}$ Ibid 182-5 (French CJ), 219-21 (Crennan J), 209-12 Hayne J), 231-7 (Keifel J), 258-60

(Bell J), 301-4 (Gaegler J).

${ }^{60}$ Ibid 184 (French CJ), 219 (Crennan J), 259 (Bell J), 300 (Gaegler J).

${ }^{61}$ Constitution s 92. See Betfair P/L v Western Australia (2008) 234 CLR 418.

${ }^{62}$ Maloney (2013) 252 CLR 168, 211 (Deane J). At 213 his Honour went on to form a view in relation to the effectiveness of other possible measures.

${ }^{63}$ Ibid 220 referring to University of California v Bakke 438 US 265, 290-1 (1978).

${ }^{64}$ Maloney (2013) 252 CLR 168, 222-3.

${ }^{65}$ Ibid 237 (Kiefel J).
} 
protected interest'. ${ }^{66}$ However, the question of determining whether a law is proportionate will require the Court to inform itself of the factual circumstance surrounding the law. ${ }^{67}$

Similarly Gaegler J equated the concepts of 'reasonableness', 'proportionality' and 'reasonable necessity' in the determination of the validity of a special measure. ${ }^{68}$ His Honour also considered the issue of the facts upon which a court can form a view of reasonable necessity. He noted these can come from a range of sources suggesting they may or may not be 'official', should desirably be 'public and authoritative' and may include inferences from statute and even 'statements from the bar'. His Honour opined that the facts must amount in practical terms to a 'persuasive burden' but not a 'legal burden of proof'. 69

One final point of significance in regard to Maloney goes to the relevance of the evolving interpretation of the Convention at international law. The CERD considers the Convention to be a 'living instrument that must be interpreted and applied taking into account the circumstances of contemporary society' ${ }^{70}$ However the Australian High Court when interpreting Article 1.4 as part of the $R D A$ adopted a different interpretive approach. The Court saw the development of international law subsequent to the enactment of the $R D A$ as not relevant to the interpretation of the domestic statute. ${ }^{71}$ On this basis, the Court rejected the argument put by the appellant, Ms Maloney, that an essential element of the legitimacy of a special measure was that the group for whose benefit the measure was put in place had been consulted in relation to the measure and consented to it.

From these two cases spanning nearly 30 years it seems fair to summarise then that the Australian High Court will not subject a purported special measure to the same level of scrutiny as that undertaken by the US Supreme Court. The Australian Court does make it clear though that the necessary factual circumstance to support the implementation of a special measure must exist both in the view of the legislature and to the court. Further should there be clear evidence (as to either existence of the need or appropriateness of the measure) before a court that there were not these factual bases the measure could be impugned.

\section{CERD}

The Australian Court's express rejection of considering the development of international law in construing the Convention as it applies in domestic law highlights

\footnotetext{
${ }^{66}$ Ibid 259 (Bell J).

${ }^{67}$ Ibid 260.

${ }^{68}$ Ibid 296 (Gaegler J). The point was reiterated at 301.

${ }^{69}$ Ibid 299.

${ }^{70}$ CERD, above n 6 [5].

${ }^{71}$ See Maloney (2013) 252 CLR 168, 181 (French CJ), 198 (Hayne J), 221-2 (Crennan J), 235 (Keifel J); 255-6 (Bell J). The matter is discussed in greater length in S Rice, 'Joan Monica Maloney v The Queen [2013] HCA 28' (2013) 8(7) Indigenous Law Bulletin 28.
} 
the need to separately consider the attitude of the CERD towards determining the legitimacy of special measures. These views are found in General Recommendation $32^{72}$ specifically at paragraphs 16 and 17 as follows:

16. Special measures should be appropriate to the situation to be remedied, be legitimate, necessary in a democratic society, respect the principles of fairness and proportionality, and be temporary. The measures should be designed and implemented on the basis of need, grounded in a realistic appraisal of the current situation of the individuals and communities concerned.

17. Appraisals of the need for special measures should be carried out on the basis of accurate data, disaggregated by race, colour, descent and ethnic or national origin and incorporating a gender perspective, on the socio-economic and cultural [Footnote: Article 2.2 includes the term 'cultural' as well as 'social' and 'economic'.] status and conditions of the various groups in the population and their participation in the social and economic development of the country.

Paragraph 18 continues with noting the requirement for consultation with and the active participation of affected communities — the point that was rejected by the Australian High Court.

A first point to note is that the CERD is discussing the design and development of special measures that would be undertaken by the legislative and/or executive arms of government, not the factual basis that is to be considered by the judiciary in considering a challenge to the legitimacy of a special measure. With that point noted, clearly the CERD considers there to be a need for accurate and comprehensive data both in relation to the need for the measure and its 'design and implementation'.

The CERD highlights this point and also addresses the need for the evaluation and monitoring of the effectiveness of special measures in paragraph 37 of the General Recommendation going to the contents of States parties' reports to the CERD in identifying that such reports should address (inter alia):

- the justifications for special measures, including relevant statistical and other data on the general situation of beneficiaries, a brief account of how the disparities to be remedied have arisen, and the results to be expected from the application of measures;

- the available mechanisms for monitoring and evaluation of the measures;

- participation by targeted groups and individuals in the implementing institutions and in monitoring and evaluation processes;

- the results, provisional or otherwise, of the application of the measures

\footnotetext{
${ }^{72}$ CERD, above $\mathrm{n} 6$.
} 
In deference to Article 2.2 the CERD also notes States parties' reports should also include:

- information on reasons why, in light of situations that appear to justify the adoption of measures, such measures have not been taken

It would appear then that in respect of the level of evidential detail required in support of the need for, design of and effectiveness of special measures, the CERD's approach is more akin to the strict scrutiny of the US judiciary than the discourse surrounding 'reasonable necessity' of the Australian High Court.

As Australia is bound to report to the CERD every two years ${ }^{73}$ the Commonwealth Government is under an obligation to demonstrate that the IBE is both 'appropriate and adapted' (or reasonably necessary) at the time of its establishment for domestic purposes. Further, for the purposes of its bi-annual report to the CERD, it must demonstrate a process of effective monitoring and evaluation of the IBE and the results it has achieved.

The following two parts of this discussion examine both of these issues. Part 3 considers whether the IBE can be considered appropriate and adapted to the task of ensuring Indigenous Australians' 'equal enjoyment or exercise of human rights and fundamental freedoms'. Part 4 examines issues relating to the monitoring and evaluation of procurement policies such as the IBE designed to achieve 'secondary objectives' in addition to the primary objective of obtaining goods and services on behalf of government.

\section{Appropriate AND AdAPted}

For present purposes, a passage from Justice Brennan's judgment in Gerhardy provides a succinct summary of the evidential task:

To determine whether the measure in question is intended to remove and is necessary to remove inequality in fact (as distinct from formal inequality) the circumstances affecting the political, economic, social, cultural and other aspects of the lives of the disadvantaged group must be known and an opinion formed as to whether the measure is necessary and likely to be effective to improve those circumstances. ${ }^{74}$

The first requirement, to establish that Indigenous Australians suffer disadvantage so as to not have 'equal enjoyment or exercise of human rights and fundamental freedoms' is so notorious that further evidence is barely necessary. Recent statements from two authorities illustrate this point.

\footnotetext{
${ }^{73}$ Convention art 9(1)(b).

${ }^{74}$ Gerhardy (1985) 159 CLR 70, 137 (Brennan J).
} 
The report Overcoming Indigenous Disadvantage: Key Indicators 2014, produced by the Steering Committee for the Review of Government Service Provision ${ }^{75}$ is a recent and comprehensive evidence source. The report provides evidence in regards to key disadvantage indicators such as:

- Life expectancy

- Young child mortality

- Early childhood education

- Literacy and numeracy

- Year 12 attainment

- Post-secondary education participation and attainment

- Employment

- Household and individual income

The report shows that Indigenous Australians are at a considerable, at times devastating, disadvantage when compared to the broader Australian community. More recently this conclusion has been reiterated by the Australian Department of Prime Minister and Cabinet in the 2015 Closing the Gap Report. ${ }^{76}$

What may not be so commonly appreciated is that the aspects of this multiple disadvantage are statistically correlated. That is, for example, an Indigenous Australian who is not in the labour force is also more likely to have lower educational standards, poorer health status and less adequate accommodation than an Indigenous Australian who is in the labour force. ${ }^{77}$

Given this correlation, one would expect that an increase in the level of economic activity undertaken by Indigenous-owned enterprises should lead to an increase in the number of Indigenous Australians in the labour force and consequentially a reduction in the social disadvantage suffered by Indigenous Australians. This expectation is supported by empirical research. ${ }^{78}$ For example, Hunter concluded that Indigenous-

\footnotetext{
${ }^{75}$ Steering Committee for the Review of Government Service Provision, Overcoming Indigenous Disadvantage: Key Indicators 2014 (Productivity Commission, 2014) ('SCRGSP Report') <http://www.pc.gov.au/research/recurring/overcoming-indigenousdisadvantage/key-indicators-2014\#thereport>.

${ }^{76}$ Department of the Prime Minister and Cabinet, Closing the Gap Report (2015) $<$ http://www.dpmc.gov.au /sites/default/files/publications/Closing_the_Gap_2015_Report_0.pdf $>$.

${ }^{77}$ SCRGSP Report, above n 75, 3112-23.

${ }^{78}$ J Altman, 'Indigenous Communities and Business: Three Perspectives, 1998-2000' (CAEPR Working Paper No 9/2001, Centre for Aboriginal Economic Policy Research, Australian National University, 2001) $<$ http://caepr.anu.edu.au /Publications/WP/2000WP9.php>; C Furneaux and K Brown, 'Australian Indigenous
} 
owned or jointly owned businesses report on average a 64 per cent Indigenous workforce. The equivalent figure for non-Indigenous business is 0.7 per cent. ${ }^{79}$

The increased participation in the labour force should in turn lead to a reduction in the social disadvantage suffered by Indigenous Australians. This expectation is also supported by empirical research. ${ }^{80}$

These findings allow us to conclude that as an increase in Commonwealth government purchasing of goods and services from Indigenous-owned enterprises leads to an increase in the level of economic activity undertaken by these firms, then this should lead to an increase in the number of Indigenous Australians in the labour force and therefore a reduction in Indigenous social disadvantage. There is also private sector evidence to suggest that procurement schemes targeting Indigenous enterprises lead to an increase in economic activity by these firms. For example a recent Commonwealth Government report noted that one corporation, Fortescue Metals Group Ltd, has awarded 156 contracts since 2011 with a total value of $\$ 1.56$ billion to over 50 Indigenous businesses. ${ }^{81}$

The link between the increased activity of Indigenous enterprise, indigenous participation in the labour force and the reduction in Indigenous social disadvantage is important as it addresses a possible concern identified by Brennan $\mathrm{J}$ in Gerhardy and noted earlier, that 'the beneficiaries of the special measure are natural persons not corporations'. ${ }^{82}$ Thus, in the context of the IBE the important link is that the advantage enjoyed by Indigenous enterprise leads to a reduction in social disadvantage suffered by natural persons.

Entrepreneurship: A Capital-Based View' (2008) 9(2) International Journal of Entrepreneurship and Innovation $133<$ http://eprints.qut.edu.au/14234/1/14234a.pdf>.

${ }^{79}$ B Hunter, 'Recent Indigenous Employment and Businesses: Whose Business Is It to Employ Indigenous Workers?' (CAEPR Working Paper No 95/2014, Centre for Aboriginal Economic Policy Research, Australian National University, 2014) 10:

$<$ http://caepr.anu.edu.au/sites/default/files/Publications

/WP/CAEPR_Working_Paper_95.pdf $>$. The figure for majority owned Indigenous businesses was $72.4 \%$.

$80 \mathrm{~N}$ Biddle, 'Income, Work and Indigenous Livelihoods' (Lecture 5, Measures of Indigenous Wellbeing and their Determinants Across the Life-course, 2011 CAEPR Lecture Series, Centre for Aboriginal Economic Policy Research, Australian National University, 2011) <http://caepr.anu.edu.au/sites/default/files/page/2011/01/ Lecture05Paper.pdf $>$.

${ }^{81}$ Department of the Prime Minister and Cabinet, The Forrest Review - Creating Parity (2014) $183<$ https://indigenous

jobsandtrainingreview.dpmc.gov.au/sites/default/files/files/The_Forrest_Review.pdf $>$. This also raises a question as to whether private sector procurement programs require characterisation as a special measure and the associated evidential analysis suggested therein; however, that matter is beyond the scope of the current discussion.

${ }^{82}$ Gerhardy (1985) 159 CLR 70, 133 (Brennan J). His Honour noted that benefits can be enjoyed collectively (in the context of Gerhardy through ownership by a statutory body corporate of land). 
The foregoing then supports the proposition that the IBE is 'appropriate and adapted' to the task of ensuring Indigenous Australians' 'equal enjoyment or exercise of human rights and fundamental freedoms'. It does not address the question of whether the IBE has or will achieve its goal. This task is considered in the following section.

\section{Monitoring and Evaluation of Effectiveness}

As noted in the introduction to this discussion, the scope of the IBE was significantly expanded in July 2015 when the new Commonwealth IPP introduced a requirement for Commonwealth agencies to ensure that a percentage of all procurement contracts ( 0.5 per cent in $2015-16$ increasing to 2.5 per cent by 2018-19) is awarded to Indigenous-owned firms and a compulsory 'set-aside' for contracts be awarded with respect to work in remote areas. However, the IBE itself has been in place since May 2011. Since that time until June 2015 according to the Australian National Audit Office only four contracts were awarded under the IBE. The following table sets out some of the detail of those four contracts. ${ }^{83}$

\begin{tabular}{|llll|}
\hline Entity & Nature of Contract & Date & Value (\$ million) \\
\hline Industry & Event Management & June 2013 & 0.1 \\
Defence & Construction & May 2014 & 0.7 \\
Defence & Construction & January 2015 & 1.5 \\
Dept Human Services & Cleaning & February 2015 & 8.3 \\
\hline
\end{tabular}

It can be seen from this table that the four contracts had a total value of $\$ 10.3$ million. The last contract awarded, in February of 2015, comprised $\$ 8.3$ million of this total value. By way of contrast, in 2013-14, the Commonwealth Government entered into 66,047 procurement contracts with a total value of $\$ 48.9$ billion. $^{84}$ During that financial year, one contract was awarded using the IBE with a value of $\$ 0.7$ million. In percentage terms, IBE contracts amounted to 0.00015 per cent of the number of contracts for 2013-14 and 0.0014 per cent of value for that year.

Some matters require noting in relation to this data. First, it will be recalled that the IBE only applied to exempt the $C P R$ Division 2 requirement for the public tender of the purchase of goods and services in excess of $\$ 80,000$ and the commissioning of construction works in excess of $\$ 7.5$ million. As such the two construction contracts listed in the table above are not strictly awarded as a result of the IBE as they are under the threshold required for the public tender of construction contracts.

Second, and perhaps more significantly, since July 2015 with the introduction of the targets contained in the IPP there has been a significant number of additional contracts let under the IBE. For example in October 2015 a further contract for

\footnotetext{
${ }^{83}$ Australian National Audit Office, Procurement Initiatives to Support Outcomes for Indigenous Australians, Report (2015) 73 ('ANAO Report')

$<$ http://www.anao.gov.au/ /media/Files/Audit\%20Reports/2015-

2016/01/ANAOreport_2015-2016_01a.pdf>.

${ }^{84}$ Ibid 31.
} 
security services valued at $\$ 9.2$ million for each of three years was let under the IBE by the Department of Foreign Affairs and Trade ${ }^{85}$ and since then several construction contracts have been let by the Department of Defence. In total these contracts would appear to be valued at approximately $\$ 50$ million. However, it is at the time of writing difficult to obtain verified confirmation of these figures and even if accurate the proportion of Commonwealth procurement taken up by Indigenous firms is only marginally altered.

This data would suggest that while the IBE may be appropriate and adapted to addressing Indigenous Australian disadvantage it has, to date, been of very limited effectiveness. This in turn highlights the need to undertake a program of monitoring and evaluating the effectiveness of the IBE as required under Article 9(1)(b) of the Convention. It also suggests that some consideration should be given to whether 'secondary objective' procurement policies more generally are effective.

\section{A The Effectiveness of Secondary Objective Procurement Policies}

Give the early experience of the IBE it is reasonable to consider whether secondary objective procurement policies are an effective special measure at all. While there is a volume of literature that considers the legitimacy of special measure procurement programs for the advantage of Indigenous peoples ${ }^{86}$ there is little published research that considers the effectiveness of these programs. Material from the US (particularly in light of the 'strict scrutiny' requirement arising from Adarand) and relating to special measure procurement programs designed to assist minority and womenowned business is the most fruitful. This indicates that while minority (including Native American-owned) businesses still receive disproportionately fewer government contracts, the disparity is less marked in areas where special measure procurement programs (in the nature of the IBE) are in place. ${ }^{87}$ Further, as at 2003 of six surveyed US federal government departments, four exceeded the overall government target of a 5 per cent procurement from socially disadvantaged businesses as did the federal government procurement overall. ${ }^{88}$ These general conclusions are supported by an analysis of a specific program (in Erie County, New York) which indicated that, while the program was effective in developing womenand minority-owned businesses that participated in the procurement program, there was a limited take up of the program. ${ }^{89}$

Aside from this generally quite high level data, however, there is little empirical analysis of the effectiveness of a particular special measures procurement programs

\footnotetext{
${ }^{85}$ DFAT, Media Release (13 October 2015).

${ }^{86}$ An excellent overview is provided in C McCrudden, Buying Social Justice: Equality,

Government Procurement \& Legal Change (OUP, 2007) 8-9.

${ }^{87}$ Enchautegui et al, above n 36.

${ }^{88}$ US Commission on Civil Rights, above n 28, 149.

${ }^{89}$ SL Wallace, 'Minority Procurement: Beyond Affirmative Action to Economic

Empowerment' (1999) 27(1) Review of Black Political Economy 73.
} 
designed to benefit Indigenous businesses. This shortcoming in the analysis of secondary objective procurement programs has been noted also in the context of programs intended to benefit small and medium enterprises (SME) generally (that is, not specifically Indigenous SMEs). Often the high level data can obscure the success or otherwise of particular programs. ${ }^{90}$

With this in mind it is useful to consider analysis of the effectiveness of some particular secondary objective procurement programs. Due to the absence of data in respect of Indigenous targeted programs, analysis of SME targeted programs act as a useful proxy, noting also that under the IBE it is only SME Indigenous firms that are eligible to participate.

Athey, Coeyy and Levin ${ }^{91}$ examine small business set-asides in US Forest Service contracts and conclude that the set-aside mechanism does achieve higher small business participation but also imposes higher costs. The authors suggest that a subsidy mechanism would produce more favourable (in terms of price and efficiency) results. Nakabayashi ${ }^{92}$ examined the effect of small business set-asides in Japanese public construction contracts. The author concluded that if the set-asides were removed there would be a significant exit of SMEs from the construction procurement market and that the resultant reduction in competition would operate to increase procurement costs. A similar conclusion was reached by Reis and Cabral. ${ }^{93}$ These authors considered the effect of the introduction of Brazilian federal law that allowed SME set-asides for contracts of a value of less than US\$35,000 and a 5 per cent bid preference in other tenders. They concluded that the introduction of the law did not affect prices and did facilitate a significant increase in SME procurement participation. However, there was also an increase in post-contract termination for poor performance. Unless remedial measures were put in place this would inevitably increase the overall cost of procurement. Examining preferential bank financing programs for SMEs, Freeman is dubious in relation to their effectiveness. ${ }^{94}$ In a study involving 800 firms employing from less than 10 to greater than 250 employees in the UK, Georghiou et al found that while procurement policies were targeted at the

\footnotetext{
${ }^{90}$ See eg C Nicholas and M Fruhmann, 'Small and Medium Enterprises Policies in Public Procurement: Time for a Rethink?' (2014) 14(3) Journal of Public Procurement 328; A Freeman, 'Challenging Myths about the Funding of Small Businesses ... Finance and Growth', Demos Finance (2013) <http://www.demos.co.uk /files/DF_Finance_for_Growth_-_web.pdf?1378216438>.

${ }^{\overline{91}} \mathrm{~S}$ Athey, D Coey and J Levin, 'Set Asides and Subsidies in Auctions' (2013) 5(1) American Economic Journal: Microeconomics 1.

92 J Nakabayashi, 'Small Business Set-Asides in Procurement Auctions: An Empirical Analysis' (2013) 100 Journal of Public Economics 28.

${ }^{93}$ P R C Reis, and S Cabal, 'Public Procurement Strategy: The Impacts of a Preference Program for Small and Micro Businesses' (2015) 35(2) Public Money and Management 103. ${ }^{94}$ Freeman, above n 90, 57.
} 
barriers faced by firms they were ineffective in removing them. ${ }^{95}$ Similarly, Nicholas and Fruhmann raise questions about the effectiveness of SME targeted procurement programs intended to foster innovation. ${ }^{96}$

The mixed assessment revealed by even this small survey highlights a number of issues in relation to the effectiveness of special measures procurement programs. First, the high level data from the US suggests that overall such programs do tend to foster targeted businesses although do not of themselves eliminate disparate access to government procurement opportunities. Second, assessment of the results for procurement programs of differing designs (not surprisingly) differ. Third, even a largely ineffective program would still require justification as a special measure to avoid being characterised as unlawful discrimination - Adarand involved a challenge to the award of a single contract, not a challenge to the overall effectiveness of the program the contract award decision was made under. Fourth, if there was a substantial evidence base to suggest that a particular program was not effective then a legitimate question may be raised as to whether that program was 'appropriate and adapted' to redressing unequal enjoyment of human rights. Fifth, recalling the provisions of Articles 2.2 and 9.1(b) of the Convention, a government aware of the ineffectiveness of a special measure procurement program could be construed as obliged not only to report this matter to the CERD but to take remedial action to improve the effectiveness of that program.

All of the above factors point to the importance of putting in place arrangements for monitoring and evaluation of the effectiveness of the IBE and, if need be, adjusting the design of the program in light of the results of that monitoring to improve its effectiveness. It is appropriate then to consider approaches to such monitoring and evaluation.

\section{B Methods of Monitoring Secondary Objective Procurement Policies}

In the context of procurement, 'monitoring' can refer to the process of contract management by the procuring agency. For the purposes of this discussion the monitoring and evaluation under examination is that of the effectiveness of the IBE. Under particular consideration is the collection of data regarding the award of contracts under the IBE and consequently the identification of methods to increase the rate of award of contracts. In the context of the IBE as a special measure, the collection of data confirming the connection between the award of contracts to Indigenous enterprise and reduction in Indigenous disadvantage and if need be adjustments in the program to enhance this connection would also be a necessary part of monitoring and evaluation.

\footnotetext{
${ }^{95}$ L Georghiou, J Edler, E Uyarra, J Yeow, 'Policy Instruments for Public Procurement of Innovation: Choice, Design and Assessment' (2014) 86 Technological Forecasting and Social Change 1.

${ }^{96}$ Nicholas and Fruhmann, above n 90, 350.
} 
The development and implementation of monitoring and evaluation methods is of course essentially a discipline in its own right ${ }^{97}$ and it is beyond the scope of this discussion to do justice to this body of knowledge. However it is appropriate to identify some key components of an effective monitoring and evaluation approach to secondary objective public procurement programs. It is useful to provide some definitions at the outset.

The OECD defines the term 'monitoring' as follows:

Monitoring is a continuous function that uses the systematic collection of data on specified indicators to provide management and the main stakeholders of an ongoing development intervention with indications of the extent of progress and achievement of objectives and progress in the use of allocated funds. ${ }^{98}$

In the same document 'evaluation' is also defined:

Evaluation is the systematic and objective assessment of an ongoing or completed project, program, or policy, including its design, implementation, and results. The aim is to determine the relevance and fulfilment of objectives, development efficiency, effectiveness, impact, and sustainability. An evaluation should provide information that is credible and useful, enabling the incorporation of lessons learned into the decision making process of both recipients and donors. ${ }^{99}$

The discrete nature of the functions of monitoring on the one hand and evaluation on the other is clear in David Storey's suggested six-step approach to the monitoring and evaluation of general SME policies ${ }^{100}$ which can be summarised as follows: ${ }^{101}$

Monitoring

Step 1

Step 2

Step 3

Evaluation

Step 4

Step 5

Step 6
Take up of program

Recipient opinions

Recipient views of impact of program

Comparison of assisted firms with 'typical' firms

Comparison with matched firms

Selection bias taken into account

\footnotetext{
${ }^{97}$ See eg A Markiewicz, and I Patrick, Developing Monitoring and Evaluation Frameworks (Sage, 2015).

${ }^{98}$ Organisation for Economic Cooperation and Development (OECD), Glossary of Key Terms in Evaluation and Results-Based Management (OECD/Development Assistance Committee, Paris, 2015) 27<http://www.oecd.org/dac/evaluation/dcdndep/39249691.pdf $>$. ${ }^{99}$ Ibid 21.

${ }^{100}$ That is to say including but not limited to procurement related policies.

${ }^{101}$ D J Storey, 'Entrepreneurship and SME Policy' (World Entrepreneurship Forum 2008)

$<$ http://www.world-entrepreneurship-forum.com/Publications/Articles>.
} 
Storey goes on to note that while steps 1 to 3 are often undertaken it is rare that a comparison with a 'control group' as required in steps 4 to 6 is completed. The methodology outlined by Storey and the view that most program review activities are limited to the monitoring and not the evaluation of funding is also a feature of the more recent analysis of SME policies in Latin America and the Caribbean undertaken by Acevedo and Tan in 2010 for the World Bank. ${ }^{102}$

To date, with the limited exception of the ANAO Report ${ }^{103}$ which reported against Step 1 and to a limited extent Step 2 of the methodology suggested above there has been no thorough going work that has undertaken a monitoring exercise of the IBE let alone the control group based evaluation suggested by authors such as Storey, Acevedo and Tan. As noted earlier, given the Commonwealth Government's obligations under Articles 2.2 and 9.1(b) of the Convention it would appear prudent to implement such a process of monitoring and evaluation.

\section{Conclusion}

The purpose of this discussion has been threefold. At a foundational level it aimed to both outline the content of the IBE and its role within the broader IPP. Building on this foundation the discussion then sought to examine the nature and requirements of a special measure under the Convention and in particular whether the IBE could be legitimately portrayed as a special measure. This examination included reference to domestic jurisprudence in several jurisdictions and the views of the CERD as contained in its General Recommendations of the CERD. The examination concluded that for the IBE to satisfy the requirements of a special measure under the Convention both under international law and (to a more limited extent) domestic law it was necessary to be able to demonstrate that the policy was appropriate and adapted to redressing unequal enjoyment of human rights by Indigenous Australians and (at least to satisfy international legal requirements) to put in place mechanisms to evaluate and monitor the operation and effectiveness of the policy.

The discussion then proceeded to examine the existing research around a number of these issues. As a result of this examination it was concluded that:

- it was demonstrable that Indigenous Australians did not have equal enjoyment of human rights and fundamental freedoms;

- measures to foster Indigenous enterprise could reasonably be expected to improve this situation; and,

- that there was evidence secondary objective procurement policies such as the IBE could be effective in so fostering Indigenous enterprise.

\footnotetext{
${ }^{102} \mathrm{G}$ L Acevedo and H W Tan, Impact Evaluation of SME Policies in LAC (World Bank Group, 2010) 13-15<http://www10. iadb.org/intal/intalcdi/PE/2010/05674.pdf $>$.

${ }^{103}$ ANAO Report, above $\mathrm{n} 83$.
} 
Accordingly the IBE can be legitimately characterised as a special measure under the Convention (and domestic law). However, in light of the ongoing obligations under Articles 2.2 and 9(1)(b) of the Convention it is incumbent on the Commonwealth Government to put in place effective processes for the monitoring and evaluation of the IBE. A possible methodological framework for such processes has been described although no such processes have been been put in place in any consistent fashion.

From the foregoing it can be concluded that the IBE as a component of the broader IPP is a significant policy initiative that has the potential to have near revolutionary impact on the disadvantage to which many Indigenous Australians are currently subjected. To achieve this potential it is important that effective processes for the monitoring and evaluation of the IBE are put in place and that the IBE itself is refined over time to reflect the outcomes of these monitoring and evaluation processes. 